\title{
PODOLANKA WYCHOWANA W STANIE NATURY, ŻYCIE I PRZYPADKI SWE OPISUJACA. NOWY TYP OSOBOWOŚCI KOBIETY W POWIEŚCI MICHAŁA DYMITRA KRAJEWSKIEGO
}

\author{
Katarzyna Wyzińska \\ Katolicki Uniwersytet Lubelski Jana Pawła II \\ ORCID 0000-0003-0385-8670
}

\begin{abstract}
PODOLANKA WYCHOWANA W STANIE NATURY, ŻYCIE I PRZYPADKI SWE OPISUJACA [PODOLANKA BROUGHT UP IN A STATE OF NATURE, DESCRIBING HER LIFE AND CASES]. A NEW TYPE OF FEMALE PERSONALITY IN THE NOVEL BY MICHAŁ DMYTRO KRAJEWSKI
\end{abstract}

\begin{abstract}
The Podolian Girl (Podolanka), the book written by Michał Dymitr Krajewski, had multiple editions and has been widely debated in press and in private circles. This novel turned out to be appealing and provocative work. The author not only introduced the innovative, though controversial concept of youth education but, what is more, he presented the new type of female protagonist in the age of the Enlightenment. On the one hand, she is not like fashionable women- she is independent, courageous and consistent in her actions. On the other hand, she is portrayed as an obedient, humble and fully aware of her lack of education. This new type of heroine is torn between world of fashionable women and the world of powerful, omnipotent and omniscient men. All her personality traits like: submissiveness and ignorantness, shyness and helplessness when it comes to asking for her rights- all of the mentioned qualities prove the success of an educational experiment. The author succeeded in providing the readers with a new literary archetype (in the light of other literary types of female protagonists of the Enlightenment) - a woman portrayed as submissive to men.
\end{abstract}

Key words: Michał Dymitr Krajewski; Podolanka

Patrząc na Podolankę, można sądzić, że twórczość Michała Dymitra Krajewskiego jest skoncentrowana głównie wokół współczesnych pisarzowi spraw społecznych. Jednak tak nie jest. Podolanka to istotnie dzieło dość szczególne, głośne, sporne i trochę niekonwencjonalne, ale jak zobaczymy później, Krajewski jest również autorem dzieł historycznych. Jak pisze Henryk Bogdziewicz, „wśród samych autorów [oświeceniowych - K.W.] nie obserwuje się potrzeby uzewnętrzniania wewnętrznych tarć związanych z reformowaniem szkół i metod nauczania" . Było to więc nieco ryzykowne

1 H. Bogdziewicz, Działalność literacka polskiego środowiska pijarskiego w dobie oświecenia, Kraków 2005, s. 410. 
posunięcie, przeciwstawiać się reformatorom z kręgów magnackich i obozu królewskiego, wydając powieść przedstawiającą odmienny obraz ówczesnego modelu i systemu edukacji. Można jednak dopatrywać się końca symbiozy między obiema grupami właśnie za sprawą Podolanki - Franciszek Zagórski, pisząc Muzeusza poete greckiego w 1796 roku, posłuży się „formą sielanki, by poruszyć problemy szkolnictwa”2. Ludwik Osiński „,zwróci uwagę na całą gamę zagadnień różnej natury w iście mistrzowski na ten czas sposób"3 w Zbiorze zabawek wierszem z 1799 roku.

Krajewski, pisząc swoją powieść o eksperymencie pedagogicznym, wzorował się na francuskiej powieści Henri-Josepha Du Laurensa, czego zresztą nie ukrywał, przekazując informacje na ten temat w wypowiedzi narratorki już w przedmowie do utworu. Dzieło okazało się na tyle śmiałą i kontrowersyjną wersją, że doczekało się w ciągu jednego roku aż siedmiu wydań.

$\mathrm{Za}$ ważne osiągnięcie biografowie uznają także kolejną książkę Krajewskiego, która ukazała się już w roku 1785 - Wojciech Zdarzyński życie i przypadki swoje opisujacy. W roku następnym, czyli w 1786, Krajewski napisał drugi tom przypadków pana Wojciecha, nadając mu tytuł Pani Podczaszyna. Poprzednią powieść dotyczącą losów Zdarzyńskiego uznaje się za pierwszą polską książkę fantastyczną, która jednak w sposób dość wyrazisty nawiązuje do powieści Krasickiego. Pan Zdarzyński jest w pewnym stopniu odpowiednikiem Doświadczyńskiego i tak jak tamten, który trafił na wyspę Nipu, ten dociera do utopijnej krainy na Księżycu. Powieść o Pani Podczaszynie natomiast uznawana jest za wersję powieści Krasickiego pt. Pan Podstoli. Jak więc widać, w kwestii twórczości fabularnej Krajewski nie jest zbyt twórczy i praktycznie bez trudu można wykazać jego umiejętność wzorowania się na twórczości innych i zdolność przystosowywania obcych wzorców do swoich potrzeb.

Są jednak również prace Krajewskiego, które, nie mając charakteru popularnego, wykazują większą samodzielność autora. Chodzi tu o pracę historyczną Dzieje panowania Jana Kazimierza od roku 1656 do jego abdykacji w roku 1668. Wcześniej napisał on także książkę o Stefanie Czarnieckim, która została wydana w roku 1787 . Wśród ważniejszych dzieł wymienia się również Gry nauk dla dzieci. Stużace dla ułatwienia ich edukacyi. Przez które tatwo nauczyć się moga: poznawania liter, sylabizowania, czytania w polskim i francuskim ięzyku [...], które wykorzystywane były jako rodzaj pomocy dydaktycznej i chociaż zostały wydane anonimowo, Krajewski jako autor został wymieniony w katalogu prowadzonym przez księży pijarów. Napisał także w wersji anonimowej Pochwate Stanisława Hieronima Konarskiego, wyda-

Ibidem, s. 411.

Ibidem. 
ną w Warszawie w 1783 roku. Oczywiście publikował także listy w słynnym sporze dotyczącym Podolanki.

Podsumowując jego dorobek literacki, można stwierdzić, że był człowiekiem niezwykle pracowitym, dociekliwym i twórczym. Chociaż często zarzucano mu kopiowanie cudzych pomysłów, skłonność do mało twórczego naśladownictwa, to jednak w swojej twórczości był na tyle kreatywny, że potrafił oceniać rzeczywistość z własnego punktu widzenia i samodzielnie decydować, które sprawy społeczne są na tyle ważne, że warto zająć się nimi we własnej twórczości. Chociaż Krajewski jest pisarzem nie tak znanym jak Ignacy Krasicki, kontakt z jego twórczością jest rodzajem odkrywczego i ciekawego spojrzenia na epokę, w której żył i działał.

Tytułowa bohaterka Podolanki Michała Dymitra Krajewskiego, wychowana ,w stanie natury, życie i przypadki swe opisująca”, przyciąga uwagę nie tylko jako postać zaprezentowana przez oświeceniowego pisarza, ale także, a może nawet przede wszystkim, jako oryginalny typ kobiety epoki oświecenia, zdecydowanie odróżniającej się od dam modnych, o których napisano już wiele. Paweł Kaczyński jako najbardziej charakterystyczne cechy ,żony modnej” wymienia ,przywiązywanie nadmiernej wagi do stroju, fryzury, urody, zdecydowane przedkładanie zajęć przy gotowalni nad gospodarskie, ludyczne podejście do życia (zabawy, spacery, teatr, spotkania towarzyskie, gra)"4. Rekonstruując zatem istotę kobiecości głównej bohaterki Krajewskiego, największą uwagę zwróci jej całkowita odmienność wobec współczesnych jej kobiet, które cechował ,słomiany zapał i nieustanne, kapryśne zmiany zdania"5. Rozpoczynając charakterystykę Podolanki Marysi, należy uwzględnić podwójny autorski zabieg kompozycyjny. Krajewski, pisząc Podolankę, stosuje narrację pierwszoosobową. W rezultacie czytelnik zapoznaje się z pamiętnikarską relacją dorosłej już kobiety, która z perspektywy minionych lat przypomina wszystkie ważne zdarzenia ze swojego życia. Mówi o dzieciństwie, dorosłości, o poznawaniu cywilizowanego świata i o małżeństwie zakończonym szczęśliwym, spokojnym życiem na wsi, o którym przecież żadna z „dam modnych” nie marzyła. Należy jednak pamiętać, że tę wspomnieniową narrację tworzy mężczyzna. Otrzymujemy zatem nie osobiste, autobiograficzne wynurzenia młodej kobiety, ale zręczną mistyfikację, czyli portret kobiety wykreowany z męskiego punktu widzenia. Sposób patrzenia na jej urodę, osobowość, funkcjonowanie w społeczeństwie, typ myślenia i przeżywania emocji od początku do końca proponuje autor-mężczyzna. Kobiecość Podolanki Marysi nie da się więc zrekonstruować bezpośrednio, jest bowiem projekcją męskich potrzeb, a może głównie obserwacji społecznych i sugestii

$4 \quad$ P. Kaczyński, Rodzina w literaturze stanisławowskiej. Motywy - konwencje - poglady, Wrocław 2009, s. 128.

$5 \quad$ Ibidem, s. 129. 
dydaktycznych, które miałyby, w przekonaniu autora, pomóc w zbudowaniu nowego typu oświeceniowej kobiety.

Punktem wyjścia powieściowej fabuły o dziewczynce poddanej eksperymentowi jest dość dziwny pomysł pewnego Hrabiego z Podola, który, by sprawdzić wpływ natury na wychowanie człowieka, umieszcza swoją dwuletnią córeczkę Marysię w specjalnym pomieszczeniu, całkowicie izolując ją od świata. Wcześniej Hrabia zadbał o to, by dziewczynka, oddana na wychowanie wieśniaczce, nigdy nie zetknęła się z ludzką mową. W izolacji, którą narratorka tylko raz nazywa w swoich wspomnieniach więzieniem, dziewczynka przebywa kilkanaście lat. Domyślamy się, że kiedy opuszcza owa „,blachą wybitą piwnicę", jak sama mówi o miejscu swojego pobytu, ma już chyba ponad 20 lat. Jest więc osobą dojrzałą, można sądzić nawet, że w pewien sposób ukształtowaną przez doznania, spostrzeżenia i emocje, jakich doświadczyła w owej piwnicy.

Krajewski, tworząc Podolankę, wzorował się na francuskim oryginale, bohaterka ma więc sporo cech pierwowzoru, ma też jednak cechy rodzime, nowe, nie występujące u innych bohaterek oświeceniowych powieści. Widać to przede wszystkim w postawie dorosłej już kobiety, która wychodzi za mąż i świadomie planuje własne życie. Widać to także już wcześniej, kiedy Marysia nie ulega powszechnym modom, kiedy ma odwagę rezygnować z modnych strojów, obowiązujących salonowych zachowań, kiedy pyta o przyczyny irytujących ją sytuacji. Docieka, krytykuje, nie akceptuje niektórych wyjaśnień ojca i przede wszystkim nie zachwyca się bezkrytycznie otaczającą ją rzeczywistością. Na tle dam modnych „Marysia jawi się jako kobieta racjonalna, dyskutująca na ważne tematy, kobieta stworzona przez Krajewskiego na przekór dominującej w powieściach kobiecości histerycznej, niepoważnej, paplającej bez przerwy i bez sensu"6. Wyżej stawia naturalność niż salonowe obycie, ceni prostotę, zdrowe otoczenie pięknej przyrody i domowe szczęście z radosną rodziną. Ma poczucie własnej wartości, czyta, dyskutuje z ojcem, krytycznie przygląda się próżnym damom, ale świadomie godzi się na dominującą rolę najpierw ojca, później męża - Ao. Sytuuje się w jego tle. Podziwia mężowski intelekt, na przykład kiedy widzi, jak szybko zapoznał się z zawartością biblioteki Hrabiego. Podporządkowuje się woli i decyzjom Ao, godząc się na jego dominującą rolę w rodzinie, ciągle przywołuje jego poglądy na temat wychowania ich dzieci. Jest dumna, że mąż nie boi się pracy, umiejętnie (chociaż się nigdy tego nie uczył) zarządza odziedziczonym gospodarstwem i dba o służbę. Bohaterka podkreśla też, że uznaje przyrodę za naturalne środowisko człowieka i nie zmusza dzieci do „wymyślnych nauk i obcych wzorów”?

\footnotetext{
6 W. Pawlik-Kwaśniewska, Codzienność eksperymentu. „Podolanka...” Michała Dymitra Krajewskiego, [w:] Codzienność i niecodzienność oświeconych. Przyjemności, pasje i upodobania, red. B. Mazurkowa, Katowice 2013, s. 260.

$7 \quad$ M. D. Krajewski, Podolanka w stanie natury wychowana, Kraków 2002, s. 90.
} 
Mąż mój starał się o to, aby im dać poznać jak najlepiej kraj własny. Znał wiele zacnych ludzi, którzy nie byli za granicą, a miano ich powszechnie za rozumnych, dobrych obywatelów i najzdatniejszych do wszelkich usług ojczyzny ${ }^{8}$.

Razem tworzą szczęśliwą rodzinę, która żyje własnym życiem, nie zabiegając o to, by być w towarzyskim centrum.

Przeprowadzony przez Hrabiego eksperyment nawiązuje do obecnej w tamtym czasie tendencji czerpania wiedzy i pomysłów od francuskich myślicieli i filozofów, co miało być jednoznaczne z ideą ,postępowości”. Izabella Zatorska w artykule Francuska edukacja postępowa w oczach Polaków z drugiej połowy XVIII wieku w sposób bardzo syntetyczny i treściwy przedstawia obecność francuskich pomysłów w edukacji polskich dzieci. Wskazuje na dużą fascynację poglądami Rousseau, które w nieco przerysowanym kształcie przedstawia Krajewski. Jak czytamy: ,,w relacjach między rodzicami a dziećmi górę biorą uznawane za nowoczesne poglądy Locke'a i Rousseau: obserwować naturę i dostosowywać do niej rytm i metody pracy, a nie odwrotnie". Pojawia się wiele informacji o relacjach rodzice - dziecko, które Krajewski całkowicie pomija, sytuując swoją bohaterkę w piwnicy bez kontaktu z matką. Początkowo pozbawia ją rodziców (i ludzi w ogóle), a w dalszej części przedstawia jedynie $\mathrm{w}$ towarzystwie ojca. $\mathrm{O}$ istocie obecności rodziców w wychowaniu i edukacji dzieci czytamy także w rozprawie Ireny Szybiak zatytułowanej $O$ rodzicielskich zaletach $i$ wadach $w$ oświeceniowej polskiej publicystyce edukacyjnej, gdzie odnajdziemy wiele informacji dotyczących „kochającego rodzica” i jego obowiązków. Według ówczesnych (w ślad za francuskimi poglądami) to rodzina i natura stanowić miały podstawy wychowania i podwaliny dobra moralnego. Historia wskazuje jednak na to, że osoba od najwcześniejszego dzieciństwa poddana wychowawczemu eksperymentowi, długo izolowana od otoczenia, nie zatraca instynktów społecznych, staje się przy tym samodzielna, krytyczna, rozsądna i zdecydowana. Jest swego rodzaju powieściowym wzorcem, który według Krajewskiego wart był popularyzacji. Według Stanisława Pietraszki „eksperymentalna powieść Krajewskiego zawierała treści dydaktyczno-utopijne dosyć wątłe, spory natomiast ładunek krytyki ówczesnego życia, i to krytyki nie tylko ogólnikowej”' ${ }^{10}$. Z tego też powodu wywołała pierwszy w literaturze polskiej tak ciekawy i gorący spór literacki. Andrzej Krzysztof Guzek stwierdza, że ,zauważalne na szpaltach prasy lat 60-tych i 70-tych (XVIII w.) różnice poglądów w sprawach lite-

Ibidem, s. 91.

$9 \quad$ I. Zatorska, Francuska edukacja postępowa w oczach Polaków z drugiej połowy XVIII wieku, [w:] W stronę Francji...Z problemów literatury i kultury polskiego Oświecenia, red. E. Z. Wichrowska, Warszawa 2007, s. 134.

10 S. Pietraszko, Doktryna literacka polskiego klasycyzmu, Wrocław 1966, s. 431. 
rackich poprzedziły w czasie pierwszą w Polsce wyraźną polemikę literacką", a sam „utwór był uwikłany w głośne europejskie polemiki wokół koncepcji pedagogicznych Rousseau"11. Zarzucano Krajewskiemu, że skarykaturował założenia wychowania w stanie natury, złagodził drastyczność i oddalił się od francuskiego pierwowzoru, a mimo to sprawił, że książka ta stała się bulwersująca i pobudzająca do publicznej dyskusji. Pojawiły się anonimowe broszury, w których autorzy, pochodzący głównie z kręgu pijarów, dyskutowali z Krajewskim o zasadach wychowawczych, które on popularyzował.

Pierwszy był List Sandomierzanki do Podolanki, napisany przez anonimowego autora już w roku wydania dzieła, czyli w 1784. Guzek, opierając się na innych badaniach, przypuszcza, że autorem prawdopodobnie był Franciszek Dmochowski albo Franciszek Siarczyński lub Neriusz Golański. Anonimowy autor Listu Sandomierzanki... zarzucał Krajewskiemu niewłaściwe rozumienie pojęcia „natura”, podkreślając, że w istocie jest to przecież tylko piwnica wybita blachą. Krytykował również wartość literacką dzieła, a nawet popełnione jakoby błędy stylistyczne, które miały wyniknąć ze zbytniego naśladowania francuszczyzny.

Inny list, tym razem List Paryżanki do Podolanki, napisany również w roku 1784 prawdopodobnie przez Franciszka Siarczyńskiego, w sposób zdecydowany zarzuca Krajewskiemu plagiat. Podtytuł jest ironicznym podkreśleniem tego faktu - List oryginatu do kopii. Krajewski, broniąc się przed zarzutami w tej głośnej publicznej dyskusji, prawdopodobnie sam napisał, aczkolwiek nie jest to potwierdzone, List Podolanki wychowanej w stanie natury do swojej przyjaciółki. Były też jeszcze dwa inne listy - Odpis męża Podolanki na list Sandomierzanki i Dialog, czyli Rozmowa Podolanki z jej mężem. Wszystkie te teksty, opublikowane w roku 1784, przypisywane są również Krajewskiemu. Mają charakter obronny, przy czym autor podkreśla dbałość o język, a także mówi o ważnej kwestii umiejętnego wykorzystania filozofii Rousseau, odpowiednio dostosowanej do polskiej rzeczywistości.

Ten istotny spór o Podolankę, który jeszcze w 1785 roku toczył się w prasie, stanowił wyraźny dowód na trafną chyba publikację Krajewskiego, którą dotknął aktualnych wówczas i ważnych kwestii na tyle mocno, że wywołało to tak gorącą dyskusję. Pojawiały się jednak zdania, że negatywna reakcja pijarów na dzieło Krajewskiego spowodowana była nie tylko brakiem akceptacji proponowanych metod wychowawczych, ale głównie urażoną ambicją. Sceny z końcowej części książki, w których Krajewski chwali księgozbiór Hrabiego, w odbiorze księży pijarów nie dość gloryfikowały dokonania naukowe ich środowiska. Mieli więc za złe autorowi ironiczne uwagi rozrzucone po książce, w których dosyć krytycznie omawia on potknięcia intelektualne autorów

\footnotetext{
11 A. K. Guzek, Polemiki literackie, [hasło w:] T. Kostkiewiczowa, A. Aleksandrowicz-Ulrich, Stownik literatury polskiego Oświecenia, Wrocław 2002, s. 512.
} 
z ich macierzystego środowiska zakonnego, których nazwisk wprawdzie nie wymienia, ale czytelnicy bez trudu ich identyfikowali. Odbierane to było jako rodzaj naśmiewania się z potknięć językowych czy merytorycznych uznanych wówczas i cenionych autorów.

Dyskutowana w prasie i w rozmowach prywatnych, wielokrotnie wydawana w ciągu roku Podolanka Michała Dymitra Krajewskiego okazała się książką niezwykle atrakcyjną i bulwersującą. Autor nie tylko zaproponował w niej nowy, cokolwiek dyskusyjny sposób wychowywania młodzieży, ale także pokazał nowy typ osobowości kobiety oświeceniowej. Typ ów z jednej strony całkowicie nie przypomina dam modnych, bohaterka jest bowiem zbyt samodzielna, śmiała i konsekwentna $\mathrm{w}$ działaniu, $\mathrm{z}$ drugiej strony na tle świata mężczyzn jawi się jako osobowość uległa, skromna i świadoma swoich intelektualnych braków. Cały czas autorytetem dla niej jest Hrabia, z którym co prawda polemizuje, zadaje mu niewygodne pytania, ale ostatecznie uznaje jego dominację i całkowicie podporządkowuje się jego woli. Kiedy patrzymy na Podolankę już jako żonę i matkę, widzimy jej uległy stosunek tym razem wobec męża. Kiedy ona zajęta była poznawaniem świata, oswajaniem się z rzeczywistością, uczeniem się manier i eleganckiego zachowania w towarzystwie, Ao, który opuścił piwnicę dużo później od niej, błyskawicznie opanował sztukę czytania, zapoznał się z zawartością księgozbioru teścia, stając się dla niego odpowiednim partnerem w dyskusji. Marysia nigdy nie osiągnęła tego poziomu intelektualnego, prawdopodobnie nie miała nawet takich planów. Poznawała obowiązujące zasady życia rodzinnego, wychowania dzieci i szukała swojego sposobu na budowanie własnego wzorca rodziny. Bez wątpienia jest to pozytywna strona jej osobowości. Owa niezależność, nieliczenie się z opinią środowiska, odwaga, by prowadzić życie bardziej zbliżone do życia chłopów niż magnaterii, świadczy o samodzielności w myśleniu i wierności własnym przekonaniom.

Analizując osobowość protagonistki widzimy, że mimo wszystko jest to jednak nowy typ bohaterki, która istnieje gdzieś pomiędzy światem modnych kobiet a światem wszechwładnych i wszechwiedzących mężczyzn. Podporządkowana obowiązującym regułom, godzi się na swoją rolę matki, która bez protestu urodzi kolejne pokolenie podobnych sobie istot. W zasadzie nie dokonuje się wprocesie wychowawczym ani w niej samej żadna zdecydowana zmiana. Podolanka zadba, by jej córki dokładnie przypominały ją samą i kontynuowały jej wzorzec budowania rodziny. Jej uległość i praktycznie nieświadomość, a nawet nieśmiałość, a także brak upominania się o przynależne jej prawa są potwierdzeniem sukcesu eksperymentu Hrabiego. Jego działania wychowawcze okazały się skuteczne. Autor Podolanki osiągnął zadawalający cel, uzyskując nowy, na tle oświeceniowych typów bohaterek literackich, ale jednocześnie uległy i podporządkowany mężczyźnie typ kobiety. 


\section{BIBLIOGRAFIA}

Bogdziewicz Henryk. 2005. Działalność literacka polskiego środowiska pijarskiego w dobie oświecenia. Kraków: „Universitas”.

Guzek Andrzej Krzysztof. 2002. Polemiki literackie. W: Teresa Kostkiewiczowa, Alina Aleksandrowicz-Ulrich. Słownik literatury polskiego Oświecenia. Wrocław: Zakład Narodowy im. Ossolińskich.

Kaczyński Paweł. 2009. Rodzina w literaturze stanisławowskiej. Motywy - konwencje poglady. Wrocław: Wydawnictwo Uniwersytetu Wrocławskiego.

Krajewski Michał Dymitr. 2002. Podolanka w stanie natury wychowana. Kraków: „Universitas".

Pawlik-Kwaśniewska Weronika. Codzienność eksperymentu. „Podolanka” Michała Dymitra Krajewskiego. W: Codzienność i niecodzienność oświeconych. 1: Przyjemności, pasje i upodobania. Red. Mazurkowa B. Katowice: Wydawnictwo Uniwersytetu Śląskiego: 253-260.

Pietraszko Stanisław. 1966. Doktryna literacka polskiego klasycyzmu. Wrocław: Zakład Narodowy imienia Ossolińskich.

Szybiak Irena. 2004. O rodzicielskich zaletach i wadach oświeceniowej polskiej publicystyce edukacyjnej. W: Nauczanie domowe dzieci polskich od XVIII do XX wieku. Red. Jakubiak K., Winiarz A. Bydgoszcz: Wydawnictwo Akademii Bydgoskiej im. Kazimierza Wielkiego: 35-46.

Zatorska Izabella. 2007. Francuska edukacja postępowa w oczach Polaków z drugiej potowy XVIII wieku. W: W stronę Francji... Z problemów literatury i kultury polskiego Oświecenia. Red. Wichrowska E., Warszawa: Wydział Polonistyki Uniwersytetu Warszawskiego: 128-140.

\section{PODOLANKA WYCHOWANA W STANIE NATURY, ŻYCIE I PRZYPADKI SWE OPISUJĄCA. NOWY TYP OSOBOWOŚCI KOBIETY W POWIEŚCI MICHAŁA DYMITRA KRAJEWSKIEGO}

Streszczenie: Dyskutowana w prasie i w rozmowach prywatnych, wielokrotnie wydawana Podolanka Michała Dymitra Krajewskiego okazała się książką niezwykle atrakcyjną i bulwersującą. Autor nie tylko zaproponował w niej nowy, cokolwiek dyskusyjny sposób wychowywania młodzieży, ale także pokazał nowy typ osobowości kobiety oświeceniowej. $Z$ jednej strony całkowicie nie przypomina ona dam modnych, jest bowiem zbyt samodzielna, śmiała i konsekwentna w działaniu, z drugiej strony jawi się jako osobowość uległa, skromna i świadoma swoich intelektualnych braków. Jest to nowy typ bohaterki, która istnieje gdzieś pomiędzy światem modnych kobiet a światem wszechwładnych i wszechwiedzących mężczyzn. Jej uległość i praktycznie nieświadomość, a nawet nieśmiałość, a także brak upominania się o przynależne jej prawa są potwierdzeniem sukcesu eksperymentu wychowawczego. Autor osiągnął w ten sposób zadawalający cel, uzyskując nowy, na tle oświeceniowych bohaterek literackich, typ kobiety uległej i podporządkowanej mężczyźnie.

Słowa kluczowe: Michał Dymitr Krajewski; Podolanka, powieść oświeceniowa, idee wychowawcze 


\section{PODOLANKA WYCHOWANA W STANIE NATURY, ŻYCIE I PRZYPADKI SWE OPISUJAСCA. НОВИЙ ТИП ЖІНОЧОЇ ОСОБИСТОСТІ В РОМАНІ МІХАЛА ДИМИТРА КРАЄВСЬКОГО}

Резюме: Обговорювана у пресі та в приватних розмовах, неодноразово публікована Подолянка Михала Димитра Краєвського, виявилася надзвичайно привабливою та шокуючою книгою. Автор не тільки запропонував новий, дещо суперечливий спосіб виховання молоді, а й показав новий тип особистості жінки Просвітництва. 3 одного боку, вона не схожа на модних леді, оскільки вона надто незалежна, смілива і послідовна в дії, з іншого боку, вона постає як покірна, скромна особистість і усвідомлює свої інтелектуальні недоліки. Це новий тип героїні, яка існує десь між світом модних жінок та світом всемогутніх і всезнаючих чоловіків. Її підпорядкованість і практично несвідомість, і навіть сором'язливість, а також відсутність відстоювання своїх прав, підтверджують успіх навчального експерименту. У такий спосіб автор досяг задовільної мети, отримавши новий тип покірної та підлеглої жінки порівняно з літературними героїнями Просвітництва.

Ключові слова: Міхал Дмитро Краєвський; Подолянка, просвітницький роман, просвітницькі ідеї 
